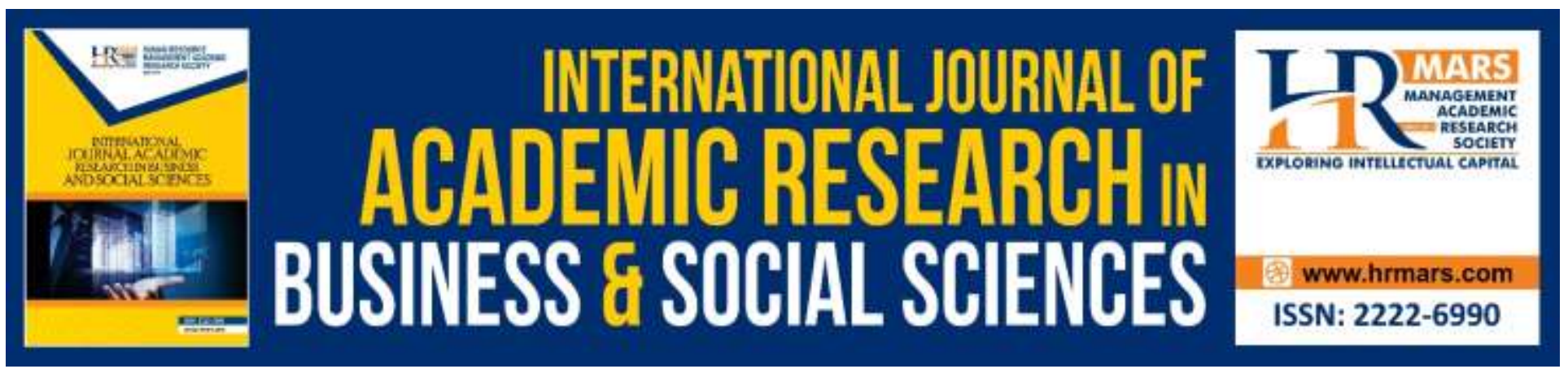

\title{
SME Policy: Comparative Analysis of SME Definitions
}

\section{Adil El Madani}

To Link this Article: http://dx.doi.org/10.6007/IJARBSS/v8-i8/4443

DOI:10.6007/IJARBSS/v8-i8/4443

Received: 24 July 2018, Revised: 11 August 2018, Accepted: 23 August 2018

Published Online: 27 August 2018

In-Text Citation: (El Madani, 2018)

To Cite this Article: El Madani, A. (2018). SME Policy: Comparative Analysis of SME Definitions. International Journal of Academic Research in Business and Social Sciences, 8(8), 100-111.

\section{Copyright: (c) 2018 The Author(s)}

Published by Human Resource Management Academic Research Society (www.hrmars.com)

This article is published under the Creative Commons Attribution (CC BY 4.0) license. Anyone may reproduce, distribute, translate and create derivative works of this article (for both commercial and non-commercial purposes), subject to full attribution to the original publication and authors. The full terms of this license may be seen

at: $\underline{\text { http://creativecommons.org/licences/by/4.0/legalcode }}$

Vol. 8, No. 8, August 2018, Pg. 100 - 111

Full Terms \& Conditions of access and use can be found at http://hrmars.com/index.php/pages/detail/publication-ethics 


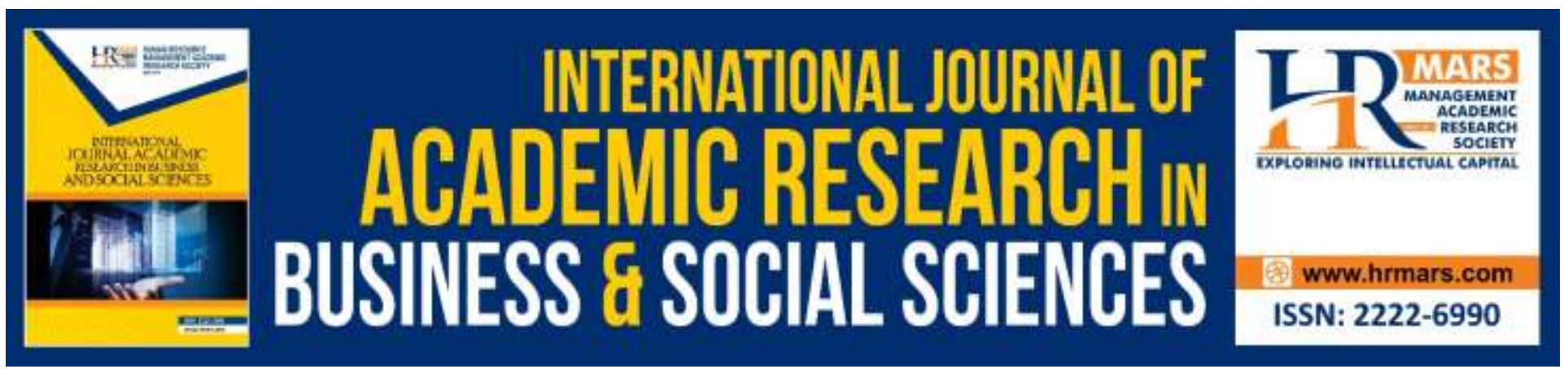

\title{
SME Policy: Comparative Analysis of SME Definitions
}

\author{
Adil El Madani \\ Belgian Ministry of Economic Affairs
}

\begin{abstract}
Since the end of the Glorious Thirties, we noted a marked increase in public policies targeting SMEs with the objective to constantly strengthen innovation and to foster the development of positive entrepreneurial ecosystems. In this context, a clear SME definition should be the guiding light determining not only the efficiency but also the adequacy of government interventions in the SME sector. We therefore explore the challenges of a single definition for SMEs through an in-depth constructivist analysis while a cross-country comparison for SME definitions is carried out.

On this basis, four points are addressed and developed. Firstly, the paper suggests that SME definitions are always a function of the associated political objectives. Secondly, through the basis of this comparison, the paper shows that the number of employees remains the most recurring criterion even though an heterogeneous and sectorial definition is the most optimal. Thirdly, with particular attention to the dynamics of evolution of the EU definition, the paper suggests that two definitions should be superimposed: a globally accepted statistical definition and a common definition for public policies that depends on the country's ecosystem where the associated SME policy is conducted. This latter point is a prerequisite to ensure both an effective SME policy and the emergence of a thriving entrepreneurial ecosystem. Fourthly, the paper points out that the problems posed by SME definitions are likely to arise again and soon for start-ups. The development of new definitions for SMEs should therefore include the opportunity to include start-ups in a singular form. This common staking would better articulate two intrinsically linked concepts.
\end{abstract}

Keywords: Public Policy, SMEs, Entrepreneurship and Start-ups.

\section{Introduction}

Since the end of the Glorious Thirties, in a context of rising unemployment in Europe and the United States, the literature on the positive impact of SMEs' in the economy has been continuously developed (Mertins and Sölter 2008). While previously large companies were considered as the main job providers, the trend reversed. A study by Professor David Birch published in 1981 entitled "Who creates job?" marked a turning point and led to a decisive awareness in this matter. His study suggested that companies with fewer than 100 employees are responsible for the overwhelming majority of jobs created. Since then, SMEs have been considered as relatively stable economic entities and started to be seen as the "backbone of the economy". 
INTERNATIONAL JOURNAL OF ACADEMIC RESEARCH IN BUSINESS AND SOCIAL SCIENCES

Vol. 8, No. 8, August 2018, E-ISSN: 2222-6990 @ 2018 HRMARS

This has resulted in intensive public policies targeting SMEs within the European Union (EU) with the objective to constantly strengthen entrepreneurship to create jobs (Mertins and Sölter 2008). In this context, a clear SME definition should be the guiding light determining not only the efficiency but also the adequacy of government interventions in the SME sector. However, an SME is not a sui generis entity. There is no universal and globally accepted definition.

As a matter of fact, over the last decades, policymakers have explored different aspects of the SME policy stakes, especially regarding the SME definition. How should SMEs be defined? Who creates this category of enterprises, and why? How do they scale up, and what can be done to support them? How do they affect the economy as a whole? In Europe, from the data-driven analysis of the Global Entrepreneurship Monitor, the SBA Fact Sheets and the Annual Report on SMEs of the European Commission, the SME Action Programme of the SME Envoys Network, to the annual OECD Scoreboard "Financing SMEs and Entrepreneurs", public institutions are putting a lot of effort into understanding and discussing what is perceived as a salient issue for the economy. SMEs face many issues in terms of access to information (Harvie and Lee 2005) and are less technology sophisticated (Gibson and Van Der Vaart 2008). Early stage SMEs are also likely to be disfavored in terms of access to finance.

Nevertheless, the creation of a clear and distinct SME category would help politicians and policymakers to provide an appropriate support to SMEs (Wapshott 2018) through the establishment of an accurate target for policy interventions (Stone 1989). This is why this article aims to better understand the approach that should be adopted to achieve an optimal definition of SMEs. We explore the challenges of a single definition for SMEs through an in-depth constructivist analysis of the EU SME Definition while a cross-country comparison for SME definitions is carried out. Finally, several recommendations which aim to promote the emergence of a more optimal SME definition are issued.

\section{Typology and Polysemy of SMEs}

The lack of a clear contemporary definition for SMEs causes excessive variability in the normative side of SME public policies. This difficulty can sometimes create normative biases since the inefficiency of SME policy is largely due to the application of the latter's blurry definitions (Dannreuther 2007). At the EU level for instance, EU Member States defend a definition of SMEs which allows a maximum of their national companies to benefit from EU support programs for SME competitiveness. In addition, the statistical definition of SMEs has been interpreted differently according to the sector concerned by the policy to be implemented : SMEs are seen differently by trade unions, venture capital investors, the banking sector and regulators (Dannreuther 2007).

These weak definitions, on the other hand, produced incomparable data that served to justify policies with very vague objectives. Indeed, SMEs are an artifact and the object of a representation obtained through several institutional channels rather than a real entity. Consequently, the enthusiasm of policymakers for the entrepreneurial aspects of SMEs could be explained by the room granted to political actors since it offered them a powerful symbol and enhanced the autonomy of governments to prosecute new political agendas, especially in periods of economic and social turbulence (Perren and Dannreuther 2013). This would explain why the politicisation of regulations and the abundant use of soft law - mainly through the promotion of "best practices" - have strongly characterized the European agenda for SME policies in the 1980s and 1990s (Dannreuther 1999), a trend that continues to this day. In this sense, the promotion of administrative simplification for companies - the EU 
INTERNATIONAL JOURNAL OF ACADEMIC RESEARCH IN BUSINESS AND SOCIAL SCIENCES Vol. 8, No. 8, August 2018, E-ISSN: 2222-6990 @ 2018 HRMARS

Capital Markets Union can also be cited - was justified by the European Union's willingness to support its SMEs. It should therefore be recalled that SME policies are the channel through which policy makers have taken measures targeting the most diverse entities in the economy.

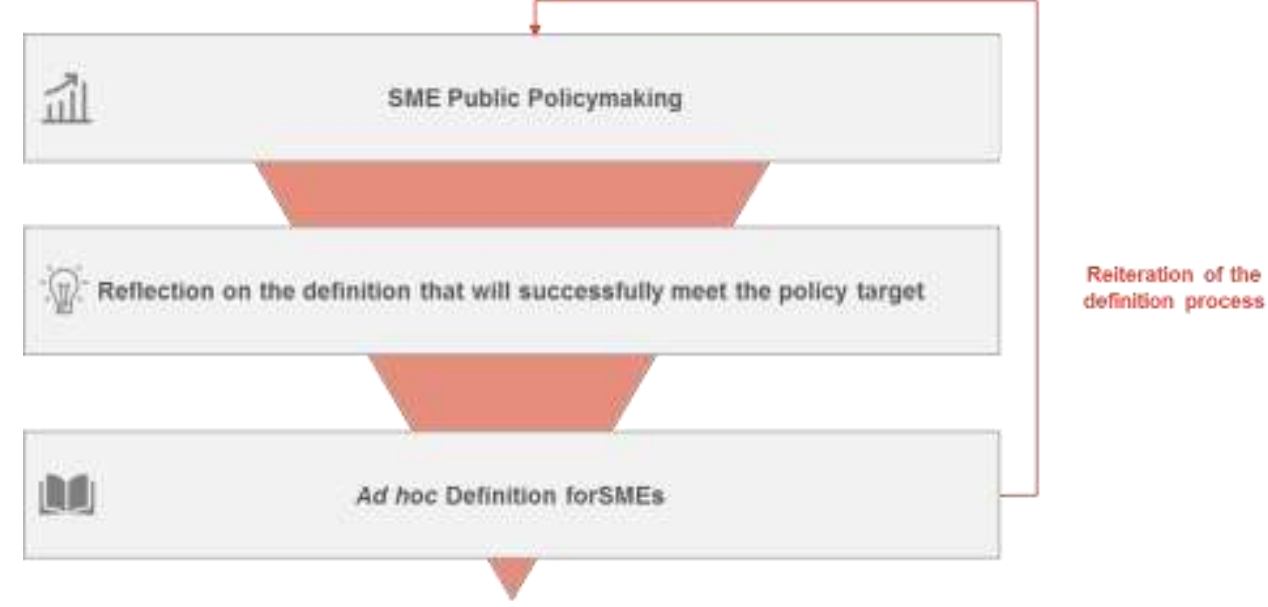

Figure 1 Process for SME Definitions

Given the number of existing criteria, it is difficult to conceive an unambiguous definition. The Woitrin Report, published in 1966, already highlighted the fact that "no satisfactory result has been and will not be obtained if we persist in trying to find a definition valid everywhere and at all times, because the notion of SMEs is necessarily relative, which means it depends on the conditions that exist in the various economies across the world and in the different branches and sectors ". The report also underlined that the construction of a definition for SMEs will depend on their related public support policies, arguing that it is "the nature of the economic measure envisaged" that will determine the contours of this definition.

Despite these difficulties, a tendency emerges from the definitions issued by public authorities: the criteria selected are generally exclusively quantitative - the most unanimously accepted criterion being the number of employees. The reason being that the qualitative criteria for SMEs would be much more difficult to measure (Hauser 2005). However, a global quantitative definition is definitely impossible, especially for accounting and financial reporting purposes (Buculescu 2013).

\section{Comparative Analysis of SME Definitions}

International organisations and states each have their own respective definition of SMEs and some of them provide several different definitions. The differences between these definitions are substantial.

\section{European Commission, OECD and World Bank}

Figure 2 shows that differences in the amounts between the definitions of the European Union, the World Bank and the OECD exist for the thresholds of the three categories of SMEs: micro, small, and medium-sized enterprises. It is striking that the differences are multiple. For example, the OECD definition imposes constraints only in terms of number of employees and does not mention turnover nor the balance sheet. 
INTERNATIONAL JOURNAL OF ACADEMIC RESEARCH IN BUSINESS AND SOCIAL SCIENCES Vol. 8, No. 8, August 2018, E-ISSN: 2222-6990 C 2018 HRMARS

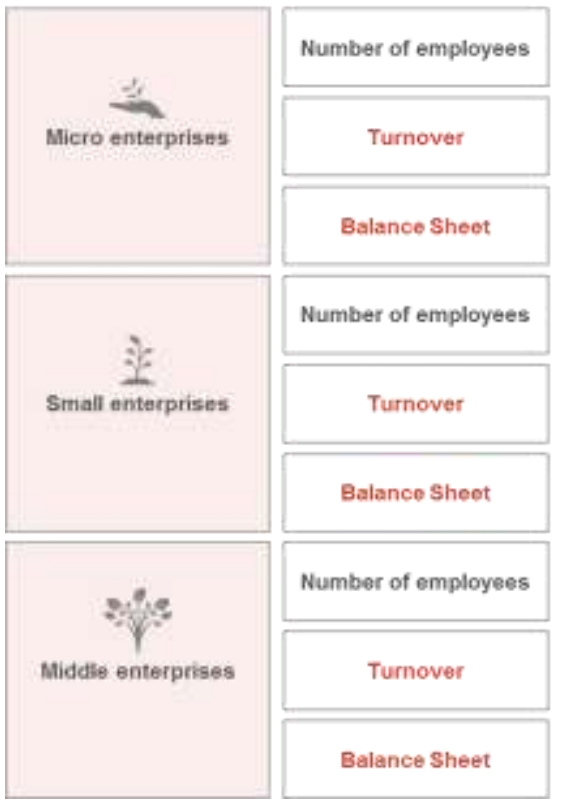

\begin{tabular}{|c|c|c|}
\hline E & Worlo bankgroup & Oy OCDE \\
\hline$<10$ & $<10$ & $<10$ \\
\hline$<\epsilon 2 \mathrm{~m}$ & $<\epsilon 3 \mathrm{~m}$ & - \\
\hline$<\epsilon 2 \mathrm{~m}$ & $<\epsilon 3 \mathrm{~m}$ & $<50$ \\
\hline$<50$ & $<50$ & - \\
\hline$<\epsilon 10 \mathrm{~m}$ & $<\epsilon 10 \mathrm{~m}$ & - \\
\hline$<\epsilon 10 \mathrm{~m}$ & $<\epsilon 10 \mathrm{~m}$ & - \\
\hline$<250$ & $<300$ & $<250$ \\
\hline$<\epsilon 50 \mathrm{~m}$ & $<\epsilon 15 \mathrm{~m}$ & - \\
\hline$<\epsilon 43 \mathrm{~m}$ & $<\epsilon 15 \mathrm{~m}$ & - \\
\hline
\end{tabular}

Table 1 Examples of SME Definitions

\section{United States, Canada and Japan}

In the United States, the Small Business Administration (SBA) regulates the definition of SMEs, which is a function not only of the ownership structure, the income and the number of employees, but also of the sector of economic activity. This last criterion is of particular importance. For example, a company manufacturing rugs can have up to 1,500 employees to be considered an SME, while a bakery cannot have more than 500 employees. Thus, there is no standardised definition that is valid for all SMEs in the United States. This differentiated approach would facilitate the implementation of relevant industrial policies (European Economic and Social Committee 2017).

In Canada, the situation is the same. There is indeed no unanimously accepted definition for SMEs: for example, the Council of Environment Ministers and the National Institute of Statistics have a separate definition (Yunke 2008). The latter also has the business sector of the company as the main criterion.

In Japan, the definition of SMEs depends not only on the sector of activity but also on the value of capital and the number of employees.

In conclusion, these three states have a definition whose first criterion is the sector of activity, which is not the case of the EU definition advocating a uniform approach that will be explained infra. For this reason, several recent studies of the European Economic and Social Committee (EESC) ${ }^{1}$ have highlighted the fact that EU SME policy considers SMEs as a homogeneous group, without, unfortunately, distinguishing between the different needs of the multiple sub-groups of enterprises

1 Étude du CESE sur l'«Évaluation de l'efficacité des politiques de l'UE en faveur des PME pour la période 2007-2015» (janvier 2017) et étude du CESE intitulée «Accès au financement pour les PME et les entreprises de capitalisation moyenne au cours de la période 2014 - 2020: opportunités et défis» (mai 2015), ci-après «les études du CESE 
INTERNATIONAL JOURNAL OF ACADEMIC RESEARCH IN BUSINESS AND SOCIAL SCIENCES

Vol. 8, No. 8, August 2018, E-ISSN: 2222-6990 @ 2018 HRMARS

falling within the definition of SMEs. This last point is strongly criticized by the EESC, which supports the fact that the lack of a "tailor-made approach" poses "a crucial problem" that prevents SME support policies from fully achieving the desired effects on these companies. The Woitrin Report, quoted above, was also in line with the EESC. It stressed the importance of the sectorial dimension of a definition for SMEs and states that "which in one sector will be considered as a large enterprise will no longer be considered in another sector, even if the importance of capital and staff are of the same order of magnitude. (...) the situation in which a company finds itself vis-à-vis the competition is an essential element ". Eventually, it should be pointed out that in $22 \%$ of the countries around the world, SME definitions vary depending on the industry (Tewari and Al. 2013).

\section{EU SME definition evolution from 1996 until now}

\section{Recommendation 96/280/CE of the European Commission of April $3^{\text {rd }} 1996$}

In Europe, given the public authorities' willingness to put in place SME support measures for several decades and the challenges of implementing these measures effectively, it has become increasingly necessary for the public institutions to explicitly circumscribe SMEs from the rest of the business population. Indeed, in addition to the multiplicity of definitions that were in use at both Community and Member State level, the definitions of the European Investment Bank and the European Investment Fund were added. However, it will be necessary to wait until 1996 to see a first draft of a common definition of SMEs at Community level. Since then, the ongoing evolution of the EU SME definition has offered important empirical insights into the value and effectiveness of different policy approaches.

The 1996 Recommendation refers to four criteria: the number of employees, the turnover, the annual balance sheet total and the independence criterion. This latter criterion only includes "companies that are not owned $25 \%$ or more of the capital or voting rights by a company or jointly by several companies that do not meet the definition of SME or small business, depending on the case". This recommendation particularly emphasizes the criterion of the number of employees, specifying that "the criterion of the number of persons employed is certainly one of the most significant and must be imposed as an imperative criterion". In this recommendation, SMEs are subdivided into only two categories: small and medium-sized enterprises.

\section{Recommendation 2003/361/CE of the European Commission of May $6^{\text {th }} 2003$}

Following this first attempt at definition, the European Commission issued in 2003 a new recommendation which contains the Community definition of SMEs valid until today. In this recommendation, which was adopted on May 6, 2003 and came into force on January 1, 2005, the main novelty (compared to that of 1996) is the introduction of an "enterprise" criterion in the definition: for an entity to be qualified as an SME, it must first and necessarily be part of the category of enterprises. More specifically, the recommendation states in its article 1 that "an enterprise is considered to be any entity engaged in an economic activity, irrespective of its legal form. This includes, in particular, self-employed persons and family businesses engaged in craft or other activities, and partnerships or associations regularly engaged in an economic activity".

This first criterion therefore places a strong emphasis on the concept of "economic activity", and echoes Council Regulation (EEC) No 696/93 on statistical units for the observation and analysis of the production system in the Community - without being as precise. The 1993 regulation stated that " The enterprise is the smallest combination of legal units that is an organizational unit producing goods 
INTERNATIONAL JOURNAL OF ACADEMIC RESEARCH IN BUSINESS AND SOCIAL SCIENCES Vol. 8, No. 8, August 2018, E-ISSN: 2222-6990 @ 2018 HRMARS

or services, which benefits from a certain degree of autonomy in decision-making, especially for the allocation of its current resources. An enterprise carries out one or more activities at one or more locations. An enterprise may be a sole legal unit ".

After this qualitative criterion, the same three quantitative criteria of the recommendation of 1996 are again included: the workforce, the annual turnover and the total of the annual balance sheet. However, as shown in Figure 3, the financial thresholds in the 2003 definition all increased from 1996.

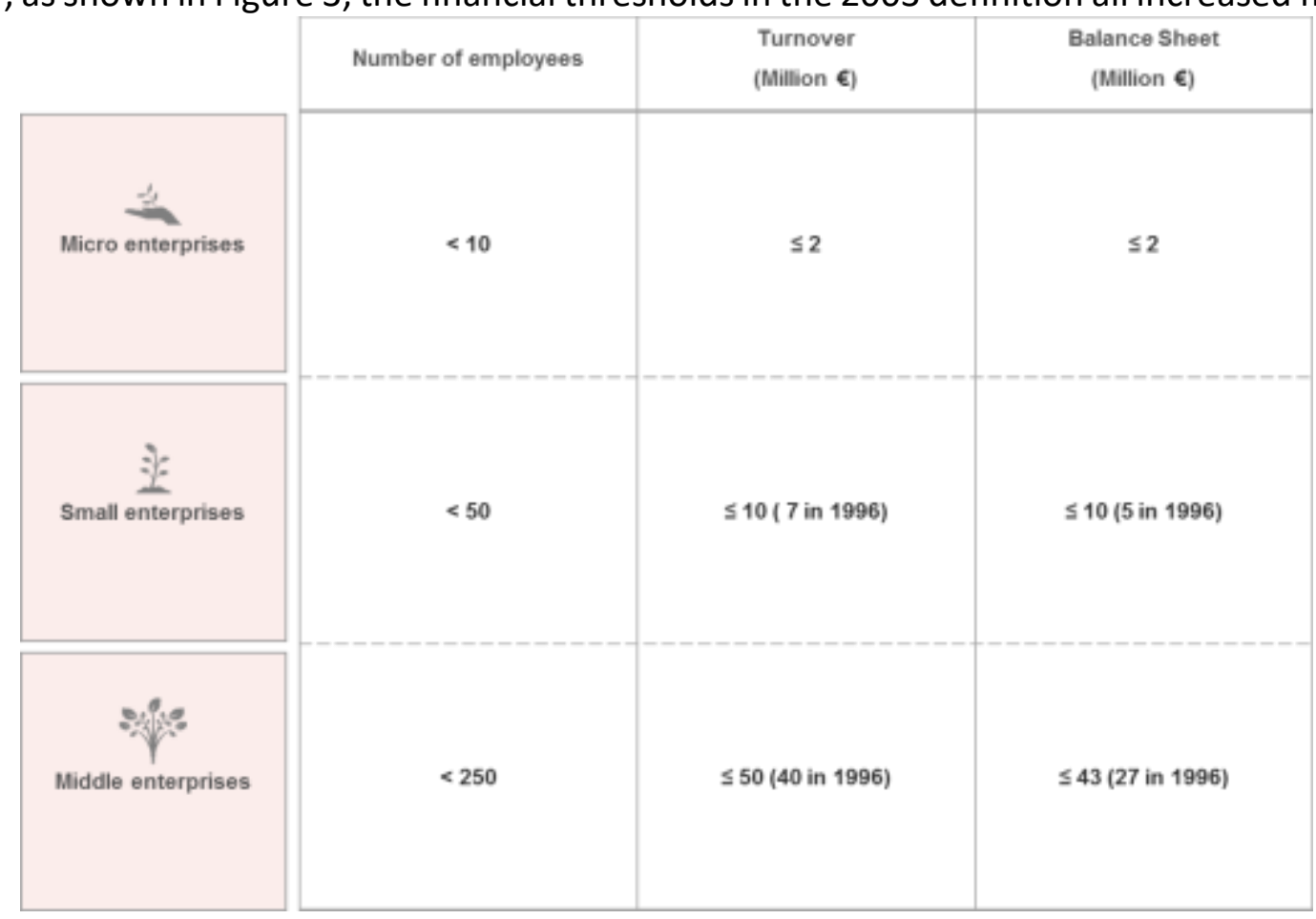

Table 2 EU Definition of 2003 in comparison with the EU Definition of 1996

In addition to the three quantitative criteria mentioned above, the criterion of independence is again taken up, but in a more accurate way. The globalization of the economy and the increasingly complex organization of economic activities (taxation, national regulations, etc.) make it necessary to understand the concept of SMEs from the perspective of company groups. Currently, it is difficult to conceive a realistic definition of SMEs without referring to the interactions that take place within these structures. Therefore, the definition makes the distinction between autonomous (totally independent) enterprises, firms with partner relationships (holding $25 \%$ to $50 \%$ of shares) and companies with links to related companies (holding more than 50\%). However, these criteria are only used to determine whether a company can benefit from a program targeting SMEs. They are not taken into account in the statistical meaning of SMEs (Mertins and Sölter 2008) because taking strictly into account all the criteria of definition is statistically not possible (Center for Strategy \& Evaluation Services 2012). In fact, European SME statistics also include companies that meet both the financial criteria and the number of employees in the 2003 definition but are owned by large companies.

The other novelty of the 2003 definition is the introduction of a new category of SMEs: microenterprises. Micro-enterprises must have fewer than 10 employees and a turnover or annual balance sheet total of less than 2 million euros.

However, the implementation of the EU SME definition remains unsatisfactory. Despite the fact that the 2003 definition is considered as the European definition par excellence for SMEs, three European directives post-2003 reflect a different definition for SMEs in their scope. Firstly, there is Directive 
INTERNATIONAL JOURNAL OF ACADEMIC RESEARCH IN BUSINESS AND SOCIAL SCIENCES Vol. 8, No. 8, August 2018, E-ISSN: 2222-6990 @ 2018 HRMARS

2013/34 / EU of 26 June 2013 on financial statements which sets out another definition for SMEs. This "accounting" definition also subdivides SMEs into micro, small and medium-sized enterprises, but with thresholds far below of those of the 2003 definition. Second, Directive 2014/65 / EU of 15 May 2014 on markets in financial instruments assigns the following definition to SMEs:

"companies that had an average market capitalisation of less than EUR 200000000 on the basis of end-year quotes for the previous three calendar years".

Third, a recent proposal for a Council Directive of 18 January 2018 on the common system of value added tax proposes a specific definition for small businesses: "any taxable person established within the EU whose annual turnover is no higher than EUR 2000000 or the equivalent in national currency "2.

Secondly, it is worth noting that the 2003 Recommendation is not binding for the Member States. It is indeed "only" a recommendation and not a regulation nor a directive. However, more than 100 pieces of European legislation refer to the 2003 definition, which in turn gives it a substantial legal force. This is the case, for example, for state aid, structural funds, research and innovation (Horizon 2020), and administrative exemptions for REACH regulations in the chemical sector.

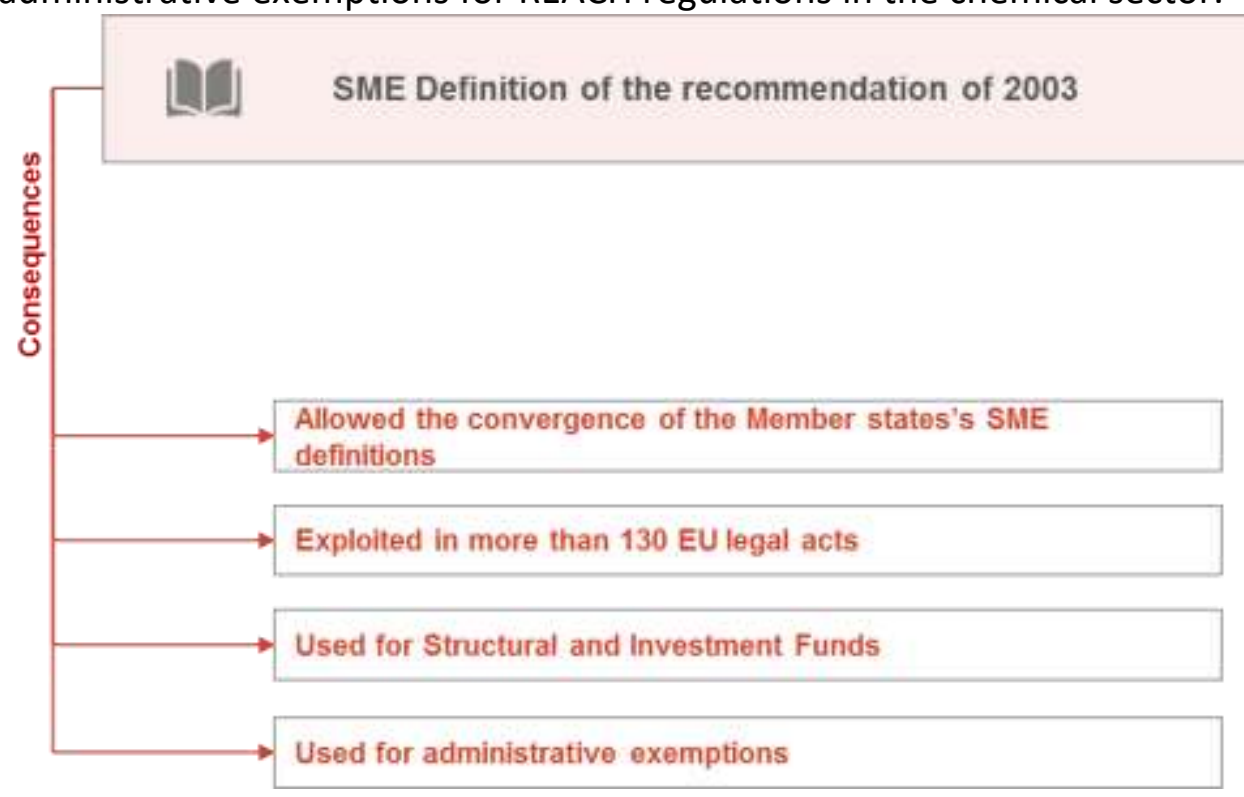

Figure 2 Consequences of the EU SME Definition of 2003

Finally, even if the European definition is not imposed on the Member States, it has many repercussions on grants and subsidies to SMEs. Indeed, the European Commission's various calls for projects for SMEs - in particular those related to the COSME ${ }^{3}$ program - target companies falling within the European definition and not within the Member States' definitions. This has resulted in situations where a company may participate in European programs for SMEs, even though it is not even considered to be an SME within the meaning of the definition of the country in which it is located. The European definition for SMEs has thus de facto a major role in the economic policies pursued to support SMEs.

Initial Impact Assessment » of June 8 $^{\text {th }} 2017$

3 Europe’s programme for small and medium-sized enterprises 
INTERNATIONAL JOURNAL OF ACADEMIC RESEARCH IN BUSINESS AND SOCIAL SCIENCES

Vol. 8, No. 8, August 2018, E-ISSN: 2222-6990 @ 2018 HRMARS

The European Commission initiated after 2003 several processes of reflection regarding not only the implementation of its SME definition but also the need to review this definition.

On June 8, 2017 the European Commission published an "Initial Impact Assessment" to confirm its willingness to start a consultation process aimed at changing the European definition of SMEs. It proposes a revision of the 2003 definition as a tool for identifying companies that need help and support (e.g. in terms of access to finance). It develops its reflection around two axes:

- Financial thresholds: these should be re-evaluated since inflation and productivity have risen significantly since 2003, with inflation growth between 2003 and 2016 being more than 26\%. These financial thresholds would also have a lock-in effect that would discourage some SMEs from growing up because of the fear of losing the SME status' benefits.

- Legal certainty: several concepts included in the definition could be better clarified so that there is less scope for interpretation.

The threshold of 250 employees, however, is not subject to any change since several studies have already pointed out that it should not be raised (Center for Strategy \& Evaluation Services 2012).

\section{Stakeholders' Opinion on the Opportunity to Revise the EU SME Definition}

The stakeholders for the revision of the definition are very numerous. For the sake of brevity, we are referring here only to the stances of European federations and unions and to the position of the European Economic and Social Committee.

\section{Union of Enterprises}

Business Europe, whose purpose is to federate the interests of European industry, expresses its wish to see Article 3 of the Annex to the 2003 Recommendation on the SME definition (relating to the independence criterion) amended in order to facilitate the SMEs' access to risk capital and to facilitate the development of SMEs financed by venture capital. The content of this amendment is not specified, however. Business Europe also notes that the Commission attaches far too much importance to its "initial impact assessment" on the support function that the definition of SMEs must take.

Eurochambers, the association of European Chambers of Commerce, considers that the current financial thresholds and the number of employees remains appropriate. Increasing the financial thresholds would not be relevant because the current definition already covers $99 \%$ of companies. Eurochambers is sensitive to the arguments for inserting a sector parameter and the life cycle phase into the definition. However, it responds to these proposals in the negative: this would prove to be too complex for administrations and businesses. Finally, it wants to see a clear and simple definition.

The European Union of Crafts and Small and Medium-sized Enterprises (UEAPME), representing the interests of artisans and SMEs, considers that the 2003 definition already fulfills its objectives. It therefore considers that the financial thresholds should be retained and that the number of employees should continue to be the main criterion. It claims that the change proposed by the European Commission (raising the thresholds) would only "dilute support for SMEs" and disadvantage SMEs that really need it. It states that the threshold of 250 employees is already very high because it covers $99.8 \%$ of companies and two thirds of employment in Europe. It justifies this 
INTERNATIONAL JOURNAL OF ACADEMIC RESEARCH IN BUSINESS AND SOCIAL SCIENCES

Vol. 8, No. 8, August 2018, E-ISSN: 2222-6990 @ 2018 HRMARS

based on the 1996 recommendation that companies with more than 250 employees already have "very strong management structures" that are sufficient to secure their market share.

UEAPME is particularly opposed to the modification of the financial thresholds according to the rate of inflation because it varies from one country to another. This criticism must be put into perspective, since it would be possible to take as a reference the lowest rate of inflation within Member States, which would therefore not penalize anyone. UEAPME also confirms that broadening the scope of the definition would run against the principles of the European Small Business Act (SBA) and that instead of broadening the definition, it would be better to target micro and small businesses. UEAPME recalls that all available data indicate that SMEs are underrepresented in European business support programs. UEAPME regrets that despite a precise definition of micro and small enterprises, too few programs target them and no economic or statistical analysis study SMEs by category.

\section{European Economic and Social Committee (EESC)}

The EESC argues that European policies in favor of SMEs should acknowledge the " heterogeneity and diversity of European SMEs " and consider the specific needs of "micro, family and" traditional " microenterprises, family and "traditional" businesses, social enterprises, liberal professions, selfemployed people and all other specific sub-groups that have quite different legal forms and models of operation ". The EESCC believes that "SME policies do not take the different needs of different categories of SMEs into account " (European Economic and Social Committee 2017).

The EESC proposes a revision of the "segmentation criteria" so that they are not based " only on size (e.g. in general, the smaller the enterprise is, the harder it is to get access to finance and the more it is in need of advice, coaching and mentoring), but also on location (cities vs small towns and remote rural areas), on life-cycle phase (start-up, scale-up), on sector (industry, trade, agriculture, tourism, etc.), etc ". Ultimately, the EESC insists that the distinction be made " on their size, lifecycle stage, location, type of ownership, sector of activity, etc. and their needs for support are quite varied depending on which sub-segment a given SME is in ".

The EESC also cites the category of "monoentrepreneurs", which represents almost half of SMEs and is virtually "excluded from the scope of support measures". The self-employed and companies without employees seem indeed to face many challenges without any political answer (Center for Strategy \& Evaluation Services 2012), even though they represent $56 \%$ of the active companies and $14 \%$ of the total employment of the European Union (European Commission 2017).

\section{Conclusion}

Our constructivist analysis suggests that, despite the European Commission's desire to clarify its definition of SMEs, an unambiguous definition should not emerge in a near future. This is largely due to the fact that the primary purpose of a definition for SMEs is to make it the target of a public policy (Center for Strategy \& Evaluation Services 2012). The definition ultimately obtained will therefore be a function of the associated political objectives. Thus, if the objective is to target larger companies in the same scope of SME support policies, the financial thresholds are likely to be revised upwards.

Furthermore, no criterion can be considered absolute, which is unfortunate for such a definition. The notion of "SME" has always varied according to the legislation to be applied. Moreover, the various stakeholders mentioned above are very reluctant to the idea of revising the definition. They most particularly fear the dilution of the support given to SMEs and undermine the arguments put forward by the European Commission in its "initial impact assessment". Nevertheless, our study shows that, even though an ideal SME definition should depend on the normative opinions of the stakeholders 
involved in its elaboration, the discourses of these stakeholders aims only to defend their own interests.

Given the challenge of such a definition and the multitude of criteria and parameters that are part of the debate today, three points should be prioritised in order to strengthen the role of both public authorities and the State as a natural and historical protector of SMEs. These three points to better define SMEs in a less ambiguous definition can be expressed as follow.

Firstly, the United States, China, Canada and Japan all have a sectorial definition for SMEs. The business sector is indeed one of the most recurrent parameters - with the number of employees, the turnover and the balance sheet - in the existing definitions (Tewari et al. 2013). The European Commission also states in its "initial impact assessment" that the objectives of the revision of the definition must ensure that "sectorial particularities are sufficiently taken into account to identify SMEs". Moreover, according to the OECD, it is quite possible that a company with 500 employees has the characteristics of an SME whereas a company of only 200 employees is managed like a large company and has all the characteristics of the latter. Defining quantitative criteria as absolute is therefore not a pragmatic approach. In the same vein, the 1966 Woitrin Report already emphasized that "the situation in which a company finds itself in relation to competition is an essential element" in order to deliver an SME definition. All these elements seem to suggest that each sector of activity needs an ad hoc definition. Thus, a debate on the desirability of a sectorial definition for SMEs must absolutely take place within the European Union.

Secondly, with particular attention to the dynamics of evolution of the EU definition, we also suggest that two definitions should be superimposed: a globally accepted statistical definition and a common definition for public policies that depends on the country's ecosystem where the associated SME policy is conducted. This last point is a prerequisite to ensure both an effective SME policy and the emergence of a thriving entrepreneurial ecosystem. Moreover, as shown in this article, public policies targeting SMEs are different from one country to another: SMEs should be defined according to the country where the policy is conducted in order to ensure good results.

Thirdly and finally, the term "SME" is becoming less and less fashionable today and appears even as old-fashioned in the face of the wave of start-ups - which are also the subject of no universal definition. This contrast is explained by the confrontation between "traditional" and "innovative" sectors. In a recent report, the European Committee of the Regions encourages the European Commission to try to clearly define start-ups. The problems posed by SME definitions are likely to arise again and soon for start-ups. The development of new definitions for SMEs should therefore include the opportunity to include start-ups in a singular form. This common staking would better articulate two intrinsically linked concepts and confer direct benefits on these two categories of enterprises.

\section{References}

Birch, D. L. (1981). Who creates jobs?. The public interest, (65), 3.

Blackburn, R., \& Schaper, M. (2012). Government, SMEs and Entrepreneurship Development: Policy. Practice and Challenges. Gower Publishing, Surrey.

Buculescu, M. M. (2013). Harmonization process in defining small and medium-sized enterprises. Arguments for a quantitative definition versus a qualitative one. Theoretical and Applied Economics, 9(586), 103-114.

Center for Strategy \& Evaluation Services. (2012). Evaluation of the SME Definition Charte européenne des petites entreprises du Conseil européen de 2000, p. 1. 
INTERNATIONAL JOURNAL OF ACADEMIC RESEARCH IN BUSINESS AND SOCIAL SCIENCES

Vol. 8, No. 8, August 2018, E-ISSN: 2222-6990 @ 2018 HRMARS

Comité économique et social européen. (2017). Améliorer l'efficacité des politiques de l'UE en faveur des PME (avis d'initiative). Rapporteure: Mme Milena ANGELOVA

Dannreuther, C. (1999). Discrete dialogues and the legitimation of EU SME policy. Journal of European Public Policy, 6(3), 436-455.

Dannreuther, C. (2007). A Zeal for a Zeal? SME Policy and the Political Economy of the EU. Comparative European Politics, 5(4), 377-399.

Dannreuther, C., \& Perren, L. (2013). The political economy of the small firm. Routledge.

El Madani, A. (2018). PME : regard sur les enjeux et obstacles d'une définition unique. Carrefour de I'Economie. 15 (1), 2-21.

European Commission. (2017). ANNUAL REPORT ON EUROPEAN SMEs 2016/2017 Focus on selfemployment

Gibson, T., \& Van der Vaart, H. J. (2008). Defining SMEs: A less imperfect way of defining small and medium enterprises in developing countries.

Harvie, C., \& Lee, B. C. (2005). 13. Public policy and SME development. Sustaining growth and performance in East Asia: The role of small and medium sized enterprises, 3(11.3), 301.

Hauser, S. B. S., Expert Meeting. (2005). "Towards better Structural Business and SME Statistics”. OECD

Mertins, V., \& Sölter, A. (2008). Définition et dénombrement statistique de la population des PME dans l'Union Européenne(No. 137). Diskussionsbeiträge.

Olusegun, A. I. (2012). Is small and medium enterprises (SMEs) an entrepreneurship?. International Journal of Academic Research in Business and Social Sciences, 2(1), 487.

Röhl, K. H. (2017). European SME policy: Recommendations for a growth-oriented agenda (No. 7/2017). IW policy paper.

Stone, D. A. (1989). Causal stories and the formation of policy agendas. Political science quarterly, 104(2), 281-300.

Tewari, P. S., Skilling, D., Kumar, P., \& Wu, Z. (2013). Competitive small and medium enterprises: A diagnostic to help design smart SME policy.

The European Committee of the Regions. (2017). Boosting start-ups and scale-ups in Europe: regional and local perspective

Thompson, J., Scott, J. M., \& Downing, R. (2012). Enterprise policy, delivery, practice and research: Largely rhetoric or under-valued achievement?. International Journal of Public Sector Management, 25(5), 332-345.

Wapshott, R., \& Mallett, O. (2018). Small and medium-sized enterprise policy: Designed to fail?. Environment and Planning C: Politics and Space, 36(4), 750-772.

Woitrin, M. (1966). Enquête sur la situation des petites et moyennes entreprises industrielles dans les pays de la CEE. Studies: Competition Series 4, 1966. 